\title{
Examining Sustainable Mobility in Low-cost Neighborhoods in Khartoum-Sudan
}

\author{
Z. E. Awad ${ }^{1}$, Z. O. Gaafer ${ }^{1}$
}

\begin{abstract}
By the beginning of the current century the state of Khartoum-Sudan starts giving direct support to low- income families by providing built houses to solve housing problem. The problem is that these neighborhoods lack proper standards of sustainable mobility. Five neighborhoods are selected as case studies. The research has two methodological phases: a comparison between neighbourhoods by criteria (geospatial data) describing their physical characteristics and field observation. The current situation of the neighborhoods were analyzed and the outcomes were compared with the UN Habitat model of sustainable neighborhood focusing on five parameters :location, proximity to potential work areas ,urban mobility street network characteristics and walkability .The research found that all the selected neighborhoods are accessible by private transportation (mini buses and cars) and within neighborhoods by Ructions. They have clear road hierarchy with no special roads dedicated for bicycles or pedestrians. Car ownership's ranging from $20-30 \%$. and there are no sufficient parking spaces. The research recommended adding sidewalks, parking spaces and green routs that can help identifying roads and improving their usability and giving priority to pedestrians, cyclists, and public transport. The research encouraged shared-use mobility services such as car sharing.
\end{abstract}

Keywords: low-cost neighborboods, sustainable mobility, road bierarchy,

\section{Introduction}

Sustainable development is an important concept yet comprehensive and complex at the same time. It was first presented in the 1987 Report of the Brundtland Commission, Our Common Future, as "meeting the needs of the present generation without compromising the ability of future generations to meet their own needs." (Holden et al. 2014). It was clearly outlined in the 17 sustainable development goals (Rio +20 ), in which Goal 11 presents a clear statement that urban development can be a major concern in sustainable issues "Make cities and buman settlements inclusive, safe, resilient and sustainable" (United Nations, 2016) . Sustainable development is seen as a process that links environmental protection with economic, social and cultural sound development. This approach to community sustainability was developed in Melbourne Australia and adopted at the Earth Summit, 2002 and is called the Melbourne Principles (UNDP 2002) and known as the four pillars of sustainability: cultural vibrancy, economic prosperity, environmental responsibility and social justice. Sustainability in regard of transportation is defined as diminishing both mobility and the negative of traffic (Clercq and Bertolini. 2003), therefore, Policies for sustainable urban development should include measures to reduce the need for movement and to provide favorable conditions for energy-efficient and

| ${ }^{1}$ Department of architecture and physical planning-Building and Road Research Institute-University of Khartoum-Sudan. 
environmentally friendly forms of transport. (Jabareen 2004). The Circles Project, as a collaborative network of colleagues and associates who have been working together in various capacities to contribute to sustainability, linked the built form of the urban development with transport in the ecological domain (The Circles Project 2007). At the macro level of the town "Sustainable transportation" is defined as "transportation services that reflect the full social and environmental costs of their provision; that respect carrying capacity; and that balance the needs for mobility and safety with the needs for access" (Jordan and Horan 1998). And at the micro level of communities (Egan.2014) identified sustainable transport and connectivity as good transport services and communication linking people to jobs, schools, health and other services. Transport facilities comprise public transport, that help people travel within and between communities and facilities to encourage safe local walking and cycling.

Sustainable development at the neighborhood level is define as a "development that responds to the local needs without compromising the ability of people globally to respond to their own needs" The Haute Quality Environmental and Economic Rehabilitation (2006). The concepts of healthy communities and livability are strongly linked with transport, as it is one of the in-put determinants of health and livability (Lowe et al 2013). Barton and Grant conceptual model of the determinants of neighborhood health and livability linked buildings and places with streets and routes at the built environment level (Barton and Grant 2013). When integrating health with planning, there are many facets of planning and design that affect health and well-being such as cycle networks that encourage healthy activities and safer environment which reduces car reliance. Today the streets as argued by Angela et al (2012) have been spaces used primarily by cars in the past they were focal points for exchange and social gathering.

Therefore, a successful sustainable urban design of neighborhood meets the needs of the community that means including the community's culture and character and the quality of infrastructure and social services as well as the design street pattern. In order to design a sustainable mobility within neighborhoods sufficient amount of work zones should be located within walking distance of the transit stop and with minimal automobile parking and maximum bicycle parking (Strong (2001)). The evaluation criteria of sustainable neighborhoods presented by The LEED (2014) identifies smart location and linkage to encourage development within and near existing communities and public transit nfrastructure, and access to quality transport. UN Habitat (2014) has developed five principles as a new strategy for sustainable neighborhood planning one of them is: Adequate space for streets and an efficient street network: The street network should occupy at least 30 per cent of the land and at least $18 \mathrm{~km}$ of street length per one $\mathrm{km}^{2} \mathrm{by}$ combining walkability and public transport catchment area. In developing countries badly located low-income housing projects place a huge burden on the residents in terms of the transport subsidy, and also results in households spending a high proportion of their meagre income on transport, that is not considered to be sustainable in the long term and leads to urban sprawl (Aucamp et al 2001). Two types of Accessibility indices within neighborhoods are developed as part of the study by Wilber Smith Associates (2008): Public Transport Accessibility Index which measure the distance to the nearest place or activity and Service Accessibility Index which measure. the number of places or activities within a given distance. They describe how efficiently with less time and travel 
distance a person can reach there.

\section{Research Methodology}

This paper presents part of a research carried to evaluate urban sustainability in low-cost neighbourhoods in Khartoum analysing six urban parameters : political management and community participation, urban morphology and typology, urban mobility, access to social infrastructure, sustainable basic infrastructure and employment and income generation The research has followed qualitative and quantitative methods which included: analysis of documents, photo documentation, observation, and statistical data.

The research has two methodological phases: (1) a comparison between the planning pattern of the selected neighbourhoods and $\mathrm{U} N$ Habitat model of sustainable neighborhood design describing their street network design and (2) a field observation. The U N Habitat model of neighborhood design is a simple model demonstrates the balance between street and other land uses (see figure (1)). In street network model, both street hierarchy and block size are considered. In an area of one square kilometer, nine vertical and nine horizontal streets are designed to form a street network. The distance between two adjacent streets is $111 \mathrm{~m}$, and the total street length is $18 \mathrm{~km}$. Street network model design in a $1 \mathrm{~km}$. square area should be design as the following:

1. The distance between two arterial routes is between 800 to $1,000 \mathrm{~m}$.

2.The distance between two adjacent streets is $100-150$.

3.The total street length is $18 \mathrm{~km}$.

Figure (1) Street network, model design

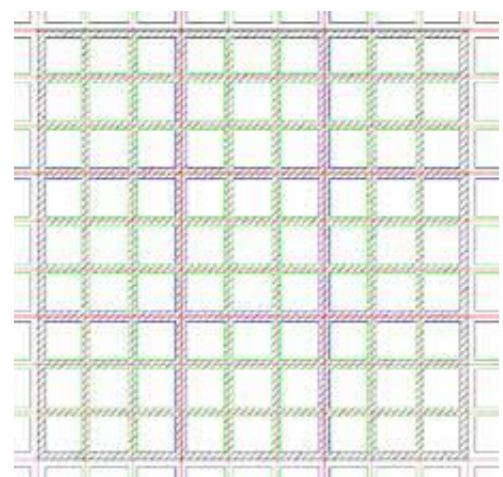

Source: UN Habitat. 2014

\section{Selections of the Case-Studies}

Sudan is a country with population of $35,482,233$ and a growth rate of $1.7 \%$. As a capital -Khartoum is concentrating 26 percent of the national population and maintaining a growth rate that is double the national rate of 3.5 percent. (Sudan Central Bureau of Statistics (2013)). The capital is comprised of three towns: Khartoum, Khartoum North and Omdurman. The area of Khartoum capital is $22142 \mathrm{Sq} . \mathrm{km}$ and the density is 239 
people/sq.km, the average size of household is 6.5 people (UN Habitat .2009). This overwhelming predominance of Khartoum attracts massive migration from different regions, shaping its multi-ethnic urban pattern that result in housing problem, so that the government gives direct support to low-income families, by providing core units. Five neighborhoods- built by the Khartoum State Housing and Development Fund- are selected as case studies: Elthawra hara 72, Elthawra hara 75, Alandalas 17, Eltelal 1 and Elwadi Elakhader 21 (see figure (2)).

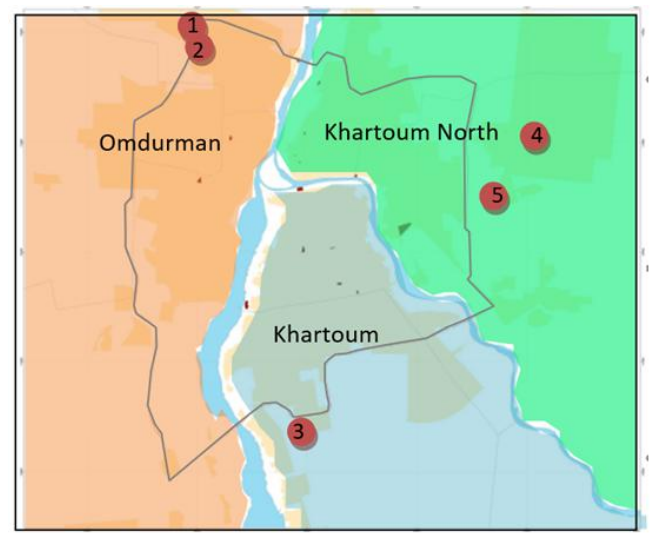

$\underline{\text { Key }}$

1 Elthawra hara 72

2 Elthawra hara 75

3 alandalus 17

4 ElWadi Elakhader 21

5 Eltelal 1

Figure (2): Location plan of the selected neighborhoods

Source: Awad and Jaafar (2016)

\section{Presentation of the Case-Studies}

\subsection{El Thawra Hara 72}

The area of the neighborhood is $993,982 \mathrm{~m}^{2}$, about one square kilometer, the neighborhood contains ten vertical and eighteen horizontal streets. The distance between two adjacent streets is $115 \mathrm{~m}$, and two arterial routs is $1000 \mathrm{~m}$ (see figure (2)), and the total street length is $16,285 \mathrm{~m}$.

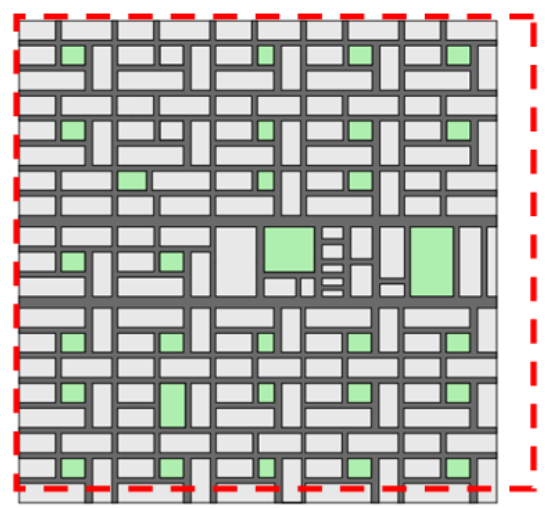

Figure (3): Design of Streets network of El Thawra hara 72.

Source (Khartoum State Housing and Development Fund Archieve). 


\subsection{E1 Thawra Hara 75}

The Area of the neighborhood is 2,139,223.296 $\mathrm{m}^{2}$, the selected area of the neighborhood is one square kilometer, it contains fifteen vertical and ten horizontal streets. The distance between two adjacent streets is $110 \mathrm{~m}$, and the distance between two arterial routs is $800 \mathrm{~m}$ (see figure (4)), and the total street length is $19,234 \mathrm{~m}$.

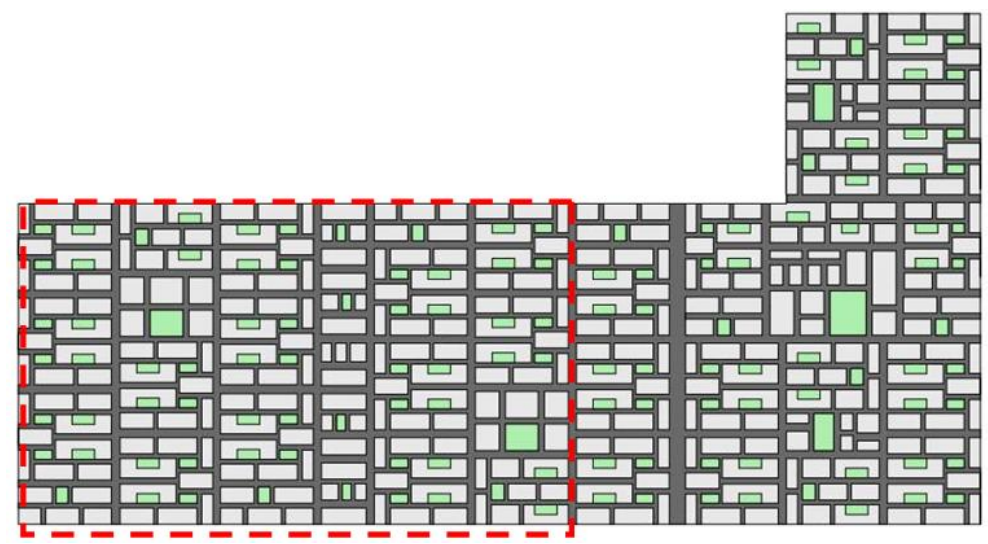

Figure (4): Design of Streets network of El Thawra hara 75.

Source (Khartoum State Housing and Development Fund Archieve).

\subsection{Andalus 17}

The area of the neighborhood is $970,920.000 \mathrm{~m}^{2}$, about one square kilometer, the neighborhood contains thirteen vertical and eleven horizontal streets. The distance between two adjacent streets is $130 \mathrm{~m}$, and the distance between two arterial routs is $700 \mathrm{~m}$ (see figure (5)), and the total street length is $10,792 \mathrm{~m}$.

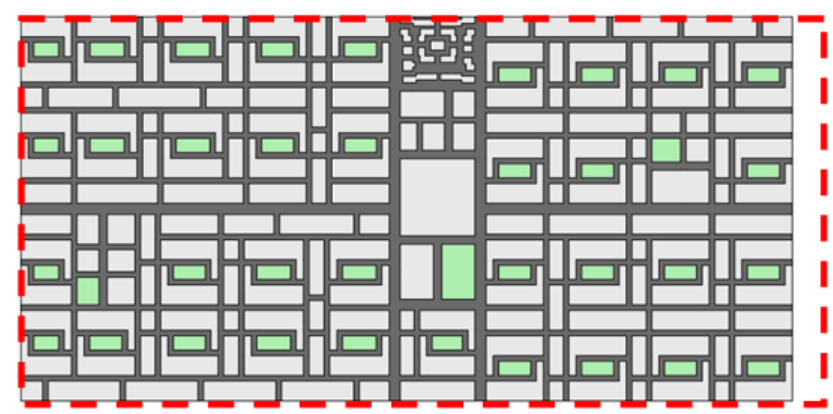

Figure (5): Design of Streets network of Andalus 17

Source (Khartoum State Housing and Development Fund Archieve).

\subsection{E1 Wadi akhdar 21}

The Area of the neighborhood is $683,280.011 \mathrm{~m}^{2}$, it is less than one square kilometer, the neighborhood contains seven vertical and thirteen horizontal streets. The distance between two adjacent streets is $110 \mathrm{~m}$, and the distance between two arterial routs is $870 \mathrm{~m}$ (see figure (6)), and the total street length is $14,052 \mathrm{~m}$. 


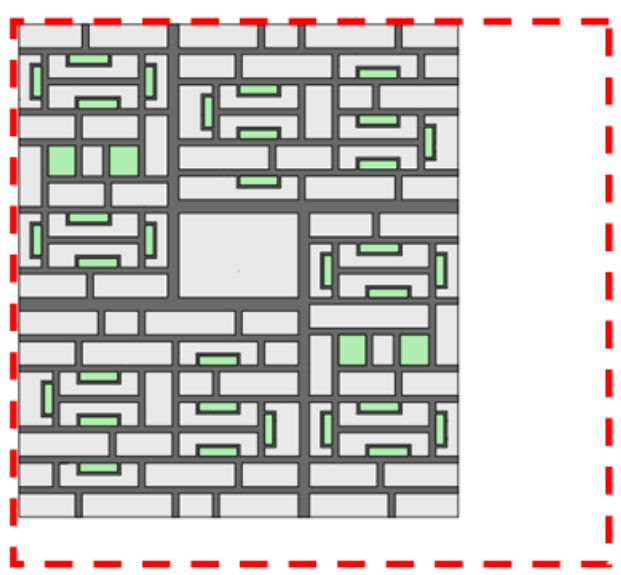

Figure (6): Design of Streets network of El Wadi akhdar 21

Source (Khartoum State Housing and Development Fund Archieve).

\subsection{E1 Tilal 1}

The Area of the neighborhood is $573,552.000 \mathrm{~m}^{2}$, it is less than one square kilometer, the neighborhood contains ten vertical and ten horizontal streets. The distance between two adjacent streets is $100 \mathrm{~m}$, and the distance between two arterial routs is $800 \mathrm{~m}$ (see figure (7)), and the total street length is $14,931 \mathrm{~m}$.

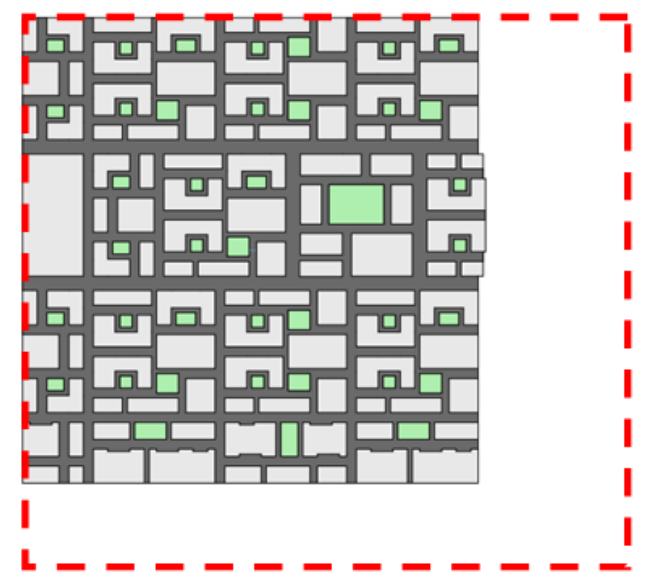

Figure (7): Design of Streets network of El Tilal 1.

Source (Khartoum State Housing and Development Fund Archieve).

\section{Analysis}

Location: Khartoum state has four circular roads that connect the capital in three different levels (Figure 8) the smaller level connects the internal administrative and service districts in the three main towns, the second level connects main residential zones through all of the localities and used to diffuse the conjunction in the center of Khartoum, the third circular route -where all the five case studies are adjacent - connects 
the industrial transportations, highway for outer state traveling lines and imported goods. The proximity of the neighborhoods to the third circular route provides a great opportunity for income generation if grasped by residents of those neighborhoods. the third circular route connects also with Eljaily petrol filtration plant, it also connect to eastern transportation rout, the road can be considered a great source of income to the users that can also limit the need to travel to the work zones if well invested ,It is assumed that when the physical separation of activities is smaller, travel needs are likely to be lower and easily met by walking, cycling, and environmentally friendly transport, Land use planning has a key role to play in the attainment of these objectives.

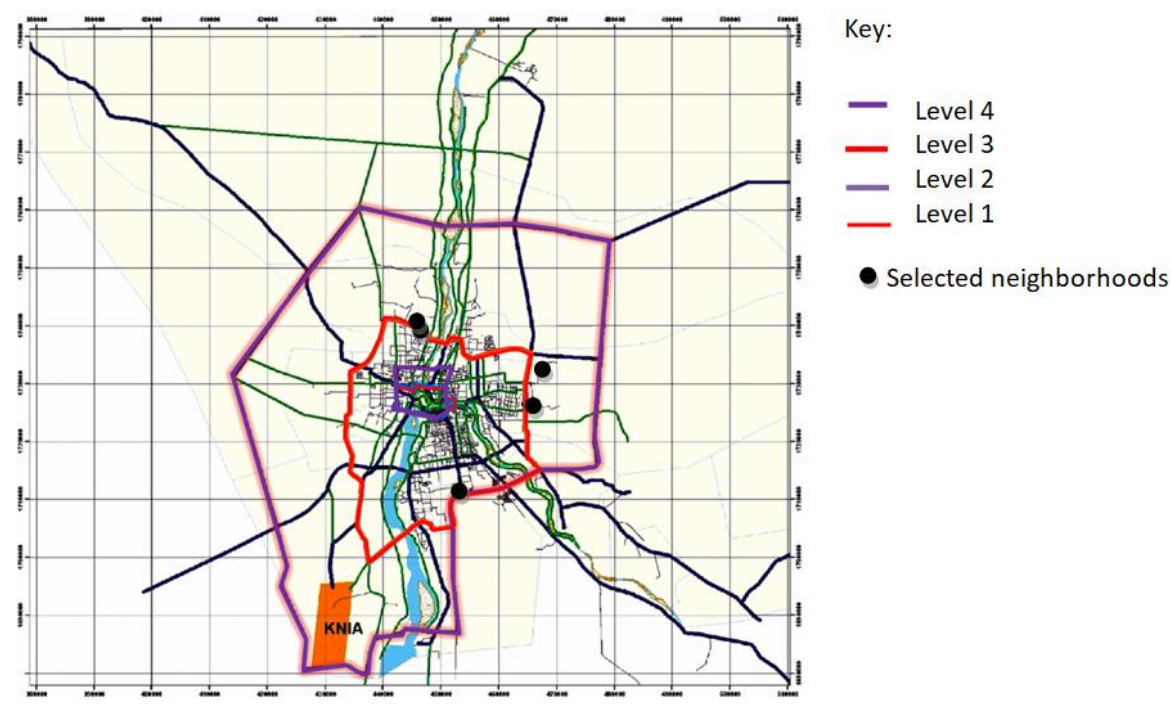

Figure 8: location of Selected neighborboods according to Khartoum state ring roads

Source (Khartoum State Structural Plan.2008).

Proximity of potential work areas: Proximity of potential work areas to the selected neighborhoods are measured using the distance to the nearest agricultural zone, to the nearest industrial area, to the nearest town center and Khartoum center (See table 5.4). The distances are not long as the nearest farming area is $2.00 \mathrm{~km}$ to Eltilal and the furthest is $6.1 \mathrm{~km}$ to ElThawra hara 72 and the nearest industrial area is $5.60 \mathrm{~km}$ to Alandalus and the furthest is $17.40 \mathrm{~km}$ to ElWadi ElAkhdar 21.

Table 1: Proximity to potential work areas. Source (the researcher).

\begin{tabular}{|l|c|c|c|c|}
\hline Neighbourhoods & $\begin{array}{c}\text { Distance to } \\
\text { town center }\end{array}$ & $\begin{array}{c}\text { Distance to } \\
\text { Khartoum center }\end{array}$ & $\begin{array}{c}\text { Distance to } \\
\text { agriculture area }\end{array}$ & $\begin{array}{c}\text { Distance to } \\
\text { industrial area }\end{array}$ \\
\hline ElThawra hara 72 & $10.800 \mathrm{~km}$ & $18.200 \mathrm{~km}$ & $6.200 \mathrm{~km}$ & $8.300 \mathrm{~km}$ \\
\hline ElThawra hara 75 & $12.100 \mathrm{~km}$ & $19.140 \mathrm{~km}$ & $6.100 \mathrm{~km}$ & $9.120 \mathrm{~km}$ \\
\hline Andalus 17 & $16.000 \mathrm{~km}$ & $16.000 \mathrm{~km}$ & $4.700 \mathrm{~km}$ & $5.600 \mathrm{~km}$ \\
\hline ElWadi ElAkhdar 21 & $20.400 \mathrm{~km}$ & $22.450 \mathrm{~km}$ & $5.800 \mathrm{~km}$ & $17.450 \mathrm{~km}$ \\
\hline ElTilal 1 & $17.000 \mathrm{~km}$ & $18.800 \mathrm{~km}$ & $2.600 \mathrm{~km}$ & $13.700 \mathrm{~km}$ \\
\hline
\end{tabular}


Land-uses: As for the land uses, street networks represent 31\% -39\% of the total area of the neighborhoods, which is higher than UN habitat recommendation (2014) for sustainable neighborhoods planning that street network should occupy $30 \%$ of the total area of the neighborhood .Open spaces in all the neighborhoods are few, they represent a small portion of the total area of the neighborhoods ranging from $6 \%$ in Eltilal 1 to $9 \%$ in Elthora hara 72 . The residential areas ranging from $48 \%$ in ElTilal 1 to $56 \%$ in ElAndalus 17 and ElWadi ElAkhdar 21. (see Table (2)).

Table 2: Main areas in case studies. Source (the researcher).

\begin{tabular}{|l|c|c|c|c|c|c|}
\hline Neighborhood & ElThawra hara 72 & ElThawra hara 75 & Andalus 17 & ElWadi ElAkhdar 21 & ElTilal 1 \\
\hline Street Area & $325,693 \mathrm{~m}^{2}$ & $769,360.552 \mathrm{~m}^{2}$ & $80,935.000 \mathrm{~m}^{2}$ & $210,773.828 \mathrm{~m}^{2}$ & $223,969.913 \mathrm{~m}^{2}$ \\
\hline Service Area & $33 \%$ & $36 \%$ & $31 \%$ & $31 \%$ & $39 \%$ \\
\hline Open Spaces Area & $45,324 \mathrm{~m}^{2}$ & $80,074.849 \mathrm{~m}^{2}$ & $317,211.071 \mathrm{~m}^{2}$ & $45,012.000 \mathrm{~m}^{2}$ & $41,535.000 \mathrm{~m}^{2}$ \\
\hline Residential Area & $4 \%$ & $4 \%$ & $7 \%$ & $7 \%$ & $7 \%$ \\
\hline Total Area & $536,269 \mathrm{~m}^{2}$ & $179,187.295 \mathrm{~m}^{2}$ & $61,998.000 \mathrm{~m}^{2}$ & $42,372.000 \mathrm{~m}^{2}$ & $33,486.000 \mathrm{~m}^{2}$ \\
\hline & $54 \%$ & $1,110,600.6 \mathrm{~m}^{2}$ & $65,783.478 \mathrm{~m}^{2}$ & $385,122.183 \mathrm{~m}^{2}$ & $274,561.087 \mathrm{~m}^{2}$ \\
\hline & $993,982 \mathrm{~m}^{2}$ & $2,139,223.296 \mathrm{~m}^{2}$ & $525,927.451 \mathrm{~m}^{2}$ & $683,280.011 \mathrm{~m}^{2}$ & $573,552.000 \mathrm{~m}^{2}$ \\
\hline
\end{tabular}

Urban Mobility: Regarding urban mobility in the capital -Khartoum, the public transportation is inefficient and based on buses and mini-buses. Most of the selected neighborhoods lack good transport connectivity with other parts of the capital they are accessible by private mini- buses used as public transportation and private cars and within neighborhoods by Ructions (see picture (1)), car ownership ranges from $20-30 \%$ of the total number of inhabitants. There are no special roads within all the neighborhoods dedicated for bicycles or pedestrians which are against the sustainable design of street network and sustainable mobility. Some inhabitants plant trees in front of their houses so that some streets are shaded (see picture (2)) but there are no sufficient parking spaces. Table (5.11) summarizes urban mobility within the selected neighborhoods.

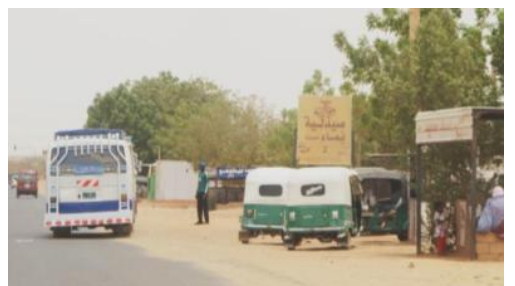

Picture 1: Public transportation - mini buses and Ructions. Source (the researcher).

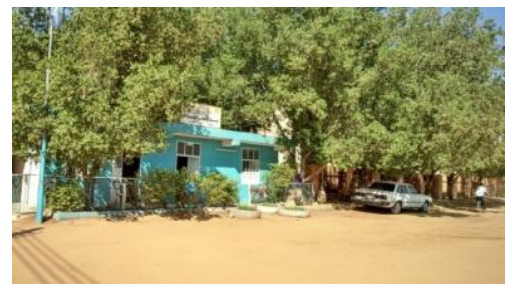

Picture 2: Shaded streets within neighborhoods. Source (the researcher). 
Table 3: Urban Mobility. Source (the researcher).

\begin{tabular}{|l|c|c|c|c|c|}
\hline neighborhoods & $\begin{array}{c}\text { ElThawra hara } \\
\text { hara } 72\end{array}$ & $\begin{array}{c}\text { ElThawra hara } \\
\text { hara } 75\end{array}$ & $\begin{array}{c}\text { Andalus } \\
17\end{array}$ & $\begin{array}{c}\text { Eltelal } \\
1\end{array}$ & $\begin{array}{c}\text { El Wadi } \\
\text { Elakhader 21 }\end{array}$ \\
\hline Public transport -ation (Bus) & No & No & No & No & No \\
\hline Private transport - ation (Ructions) & Yes & Yes & Yes & Yes & Yes \\
\hline Private transport -ation (minibus) & Yes & Yes & Yes & Yes & Yes \\
\hline Bicycle paths & No & No & No & No & No \\
\hline Pedestrian ways & No & No & No & No & No \\
\hline Paved roads & Yes & Yes & Yes & Yes & Yes \\
\hline Car ownership & $25 \%$ & $30 \%$ & $25 \%$ & $20 \%$ & $27 \%$ \\
\hline
\end{tabular}

Streets network Characteristics: The distance between two adjacent streets in the selected neighborhoods ranging from $100 \mathrm{~m}$ to $130 \mathrm{~m}$ which is near to the recommended distance- $115 \mathrm{~m}$. The distance between two adjacent arterial streets in all the neighborhoods are within the recommended range $800-1000$ except in Andalus 17 which is below the recommendation. The total street length in all the neighborhoods are less than the recommendations except in ElThawra hara 75 which is more than the recommendation. Some of the peripheral roads and a few internal roads of the neighborhoods are paved. Table (4) summarizes characteristics of the streets network of the selected neighborhoods

Table 4: Streets network characteristics. Source (the researcher).

\begin{tabular}{|l|c|c|c|}
\hline neighborhoods & Total street length & $\begin{array}{c}\text { distance between } \\
\text { two adjacent streets }\end{array}$ & $\begin{array}{c}\text { distance between two } \\
\text { adjacent arterial streets }\end{array}$ \\
\hline Thawra hara 72 & $16,285 \mathrm{~m}$ & $115 \mathrm{~m}$ & $1000 \mathrm{~m}$ \\
\hline Thawra hara 75 & $19,234 \mathrm{~m}$ & $110 \mathrm{~m}$ & $800 \mathrm{~m}$ \\
\hline Andalus 17 & $10,792 \mathrm{~m}$ & $130 \mathrm{~m}$ & $700 \mathrm{~m}$ \\
\hline ElWadi ElAkhdar 21 & $14,052 \mathrm{~m}$ & $110 \mathrm{~m}$ & $870 \mathrm{~m}$ \\
\hline Tilal 1 & $14,931 \mathrm{~m}$ & $100 \mathrm{~m}$ & $800 \mathrm{~m}$ \\
\hline
\end{tabular}

All the selected neighborhoods have good hierarchy of roads that feeds the neighborhood, support different functions and play a critical role in the safety of the neighborhood. The road widths of the case studies are starting from the main arterial roads $(20-24 \mathrm{~m})$ all the way to cluster roads that leads to the cluster open area $(8-10 \mathrm{~m})$ as shown in table (5).

Table 5: Hierarchy of roads. Source (the researcher).

\begin{tabular}{|l|c|c|c|c|c|c|c|}
\hline neighborhoods & $8 \mathrm{~m}$ & $10 \mathrm{~m}$ & $12 \mathrm{~m}$ & $15 \mathrm{~m}$ & $20 \mathrm{~m}$ & $24 \mathrm{~m}$ & $40 \mathrm{~m}$ \\
\hline ElThawra hara 72 & & $*$ & $*$ & $*$ & & $*$ & \\
\hline ElThawra hara 75 & & $*$ & $*$ & $*$ & $*$ & & $*$ \\
\hline ElAndalus 17 & & $*$ & & $*$ & $*$ & & \\
\hline ElWadi ElAkhdar 21 & $*$ & & $*$ & & $*$ & $*$ & \\
\hline ElTilal 1 & $*$ & & & $*$ & & $*$ & \\
\hline
\end{tabular}

Walkability: Walkability in the selected neighborhoods is measured by the walking distance to key services; which ranging from $280 \mathrm{~m}$ in ElWadi ElAkhdar 21 to $625 \mathrm{~m}$ in El Thawra hara 75 as shown in table (6). Two neighborhoods only (El Thawra hara 72 
and Andalus 17) have good walkability according to the recommendation of UN Habitat - 400 to $450 \mathrm{~m}$. It was noticed that the shape of the neighborhood and the location of the service center play a key role in walkability, therefore ElThawra hara 75 has a longitudinal shape so that it has the longest walking distance to service center. Encouraging public transport in the selected neighborhoods is measured by the walking distance to bus stations; catchment area for minibuses in the selected neighborhoods ranging from $500 \mathrm{~m}$ in El Thawra hara 75 to $1000 \mathrm{~m}$ in El Thawra hara 72 as shown in table (6), also two neighborhoods only (El Thawra hara 75 and ElWadi ElAkhdar 21) encourage public transportation as the recommended distance by UN Habitat is 320-640 $\mathrm{m}$ to each bus station.

Table 6: Walking distance to service center and Minibus catchment area radius Source (the researcher).

\begin{tabular}{|l|c|c|}
\hline Neighborhoods & Walking distance to service center & Minibus catchment area radius \\
\hline El Thawra hara 72 & $430 \mathrm{~m}$ & $1000 \mathrm{~m}$ \\
\hline El Thawra hara 75 & $625 \mathrm{~m}$ & $500 \mathrm{~m}$ \\
\hline Andalus 17 & $400 \mathrm{~m}$ & $700 \mathrm{~m}$ \\
\hline ElWadi ElAkhdar 21 & $280 \mathrm{~m}$ & $615 \mathrm{~m}$ \\
\hline El Tilal 1 & $570 \mathrm{~m}$ & $770 \mathrm{~m}$ \\
\hline
\end{tabular}

\section{Conclusion}

The existing process of allocating housing units to individuals without regard to where they work is not practical and needs some intervention. It is more economic to locate housing projects on more accessible land. The increase in land costs can be easily recovered by the savings in transport subsidy. Starting with choice of location of the selected neighborhoods most of them are adjacent to the third loop road that connects the industrial routes in Khartoum. Two neighborhoods are adjacent to potential working areas: Andalus 17 is adjacent to a big business center -Elkalakla and El tilal is next to an agricultural project. Street networks represent $31-39 \%$ of the total area of the neighborhoods, which is higher than UN habitat recommendation that indicates inefficient planning leading to urban sprawl.The majority of the residents use public transportation which is a more sustainable solution as only $20-30 \%$ of the residents own vehicles. Most of the selected neighborhoods lack good transport connectivity with other parts of the capital. All neighborhoods' roads have good hierarchy; the road widths range from 40 to $20 \mathrm{~m}$ for the arterial roads and $8 \mathrm{~m}$ for local roads. Streets are not walkable and there are no cyclist friendly routes, and lack sufficient parking spaces. Two neighborhoods only (Thawra hara 72 and Andalus 17) have good walkability and also two neighborhoods only (Thawra hara 75 and ElWadi ElAkhdar 21) encourage public transportation according to the recommendation of UN Habitat.

\section{Recommendations}

To improve sustainable mobility in neighborhoods several actions should be taken as follows: 
- Choose accessible locations for housing projects, locations that can keep settlements compact and more energy efficient.

- Improve transportation connectivity of the neighborhoods with other parts of the capital.

- Increase the compactness of the neighborhoods by reducing the area of streets network.

- Locate main services at the center of neighborhoods to improve walkability and provide sub-centers to reduce walking distances.

- Arrange the public transport routes so that a bigger area of the neighborhood is provided by public transport.

- Encourage public transport, bicycles and even mobility by walking.

- Promote bicycle usage to students and nearby workers by providing adequate facilities and cultural intervention strategies to make bicycles popular.

- Emphasize the good hierarchy of streets by designing streets themselves, adding sidewalks, and green routs that can help identifying the streets and improve their usability.

- Improve the pedestrian paths by providing detailed designs to different street widths that shows cars routes, green lines, infrastructure, bike lines and pedestrian paths.

- Separate lanes for bicycle routes and sidewalks should also be considered in the design.

-Provide Sufficient parking space.

- Introduce Shared-use mobility services such as car sharing, which was once used in Sudan.

\section{Reference}

Angela, M.G. Giele,S. Barbosa (2012).Sustainable Neighborhoods and Social Housing Urban Projects: A Comparison between Brazilian and European Practices. World Congress on municipal engineering and Sustainable Communities.

Aucamp C. A. and Moodely G. Y. (2001). Making Low-Cost Housing Projects More Accessible for Public Transport in Ethekwini:What are the Cost? Traffic and Transportation Department, City Engineers Unit, PO Box 680, Durban.

Awad,Z,E and Jaafer,Z. (2016).Sustainability evaluation for low-cost housing projects in Sudan with special reference to Khartoum State Fund for Housing and Development projects. Journal of Engineering and Architecture. Volume 4, No.2. ISSN 2334-2986 (Print) 2334-2994 (Online) the American Research Institute for Policy Development.

Barton, H. and Grant, M. (2013) Urban planning for healthy cities: A review of the progress of the European Healthy Cities Programme. Journal of Urban Health, 90 (1). pp. 129-141. ISSN 1099-3460 Available from: http://eprints.uwe.ac.uk/16288

Clercq, F, and Bertolini. L. (2003). Achieving sustainable accessibility: An evaluation of policy measures in the Amsterdam area. Built Environment 29 (1): 36-47.

Circles of Sustainability. (n.d.) http://www.circlesofsustainability.org Retrieved march 2018.

Egan. J. (2014). The Egan Review Skills for Sustainable Communities. In the common goal:Defing and measuring sustainable communities . london: RIBA Enterprises Ltd

Holden E, Linnerud K and Banister D. (2014). Sustainable development: Our Common Future revisited. Global Environmental Change 26. pp 130-139.

Jabareen, Y. (2004). A knowledge map for describing variegated and conflict domains of sustainable development. Journal of Environmental Planning and Management 47 (4): 632-642.

Jordan D, and Horan T, (1998). Identification and Prioritization of Environmentally Beneficial Intelligent Transportation Technologies. Report prepared for California PATH Program, Berkeley, CA: California PATH. 
Leed. (2014). The Leed $v 4$ for Neighbourbood Development. U.S Green Building Council.

Lowe, M., Whitzman, C., Badland, H., Davern, M., Hes, D., Aye, L., Butterworth, I. and Giles-Corti, B. (2013), Livable, healthy, sustainable: What are the key indicators for Melbourne neighborhoods? Research Paper 1. Place, Health and Livability Research Program, University of Melbourne.

Strong, k. s. (2001). sustainable urban neighborboods. florida: the graduate school of the university of florida.

Sudan Central Bureau of Statistics. (2013). Sudan in figure 2008-2012. Ministry of the Capinet-Sudan.

The Haute Quality Environmental and Economic Rehabilitation. (2006). The Haute Quality Environmental and Economic Rehabilitation.

UN Habitat. (2014). a-new-strategy-of-sustainable-neighbourhood-planning-five-principles. Retrieved august 2017, from unhabitat.org: https://unhabitat.org/

UN Habitat. (2009). Urban Sector Studies and Capacity building for Khartoum State. Khartoum: UN Habitat.

United Nations. (n.d.). Sustainable Development Goals SDGs. Retrieved October 2016, from Sustainable Development: www.sustainabledevelopment.un.org

UNDP. (2002). Melbourne Principles for Sustainable Cities. United Nations Environment Programme Division of Technology, Industry and Economics

Wilber Smith Associates. (2008). Study on Traffic and Transportation Policies and Strategies in Urban. Areas in India; Ministry of Urban Development: New Delhi, India. 